\title{
DISJECTA MEMBRA: LA ESCRITURA DE JUAN AGUSTÍN PALAZUELOS FRENTE A SU RECEPCIÓN CRÍTICA ${ }^{1}$
}

\author{
David Wallace $C$. \\ Universidad de Chile \\ dwallace@uchile.cl
}

RESUMEN / ABSTRACT

El artículo propone una lectura de la obra del novelista chileno Juan Agustín Palazuelos (1936-1969) considerando, en primer lugar, las disímiles impresiones de su recepción crítica. Con ello, se pretende dar cuenta de una poética autorial que desafió, excedió y frustró las expectativas de un exiguo circuito de críticos. La multiplicidad de recursos escriturales de la obra palazueliana es abordada a partir del concepto de disjecta membra, a través del cual es posible establecer vínculos con las nociones de monstruosidad, exceso, melancolía, espectáculo, anamorfosis y simulación, entre otros.

Palabras Clave: Juan Agustín Palazuelos, recepción crítica, corpus, disjecta membra, melancolía.

This article proposes a reading of the work by the chilean novelist Juan Agustin Palazuelos (1936-1969) considering, first, the different impressions of its critical reception. Therefore we intend to identified the strategies of Palazuelos's poetics that had defied, exceded and frustrated the expectations of a meager group of critics. The multiplicity of his scriptural resources will be approached from the concept of disjecta membra, trough wich it is posible to establish links with the notions of monstrosity, excess, melancholy, spectacle, anamorphosis and simulation, among others.

KEYWORDS: Juan Agustín Palazuelos, criticalreception, corpus, disjecta membra, melancholy.

1 Agradezco a mis ayudantes Andrés Soto y Samuel Espíndola por su colaboración en la formulación y edición de este trabajo. 


\section{INTRODUCCIÓN}

¿Dónde instalar un marco poético y estético para abordar los textos de Juan Agustín Palazuelos? Las posibilidades son múltiples. Una de ellas, acaso la más urgente por el grávido silencio sobre este autor, es inscribirlo simultáneamente en el adentro y el afuera de su producción y recepción crítica. Pero la paratextualidad ${ }^{2}$ de Palazuelos es escasa. Quizás porque sus textos no comprenden más que un ensayo, un cuento, algunas entrevistas y artículos, las antinovelas de las que me ocuparé y sus respectivas críticas literarias: de él y sobre él. El ensayo "Las Indias eran colonias" (1956) discute los aspectos positivos y negativos de la conquista de América en el enfrentamiento de la representación de esta empresa como leyenda negra o dorada en términos fundacionales. El cuento "Un llamado a Patricia" (1963) explora la imposibilidad de consecución de la performatividad, pues la llamada nunca se realiza: difiere o aplaza, desde las divagaciones infantojuveniles, el cumplimiento. Por otra parte, la filiación huidobriana queda de manifiesto en el artículo "Discutibles cuatro grandes de la literatura chilena" (1963), donde pone en cuestión los pilares del canon literario chileno, así como también se exhibe una oposición, desde el punto de vista crítico, a la perspectiva que anima de sentido a la crítica de Alone y, huelga decir, de Raúl Silva Castro. Otro artículo, "A propósito de la agonía del 'Mercure de France’” (1965), reclama

\footnotetext{
Según Genette, paratexto es todo aquello que hace que el texto devenga libro (o cualquier otro soporte material) y se proponga al público como tal: "El paratexto, pues, se compone empíricamente de un conjunto heteróclito de prácticas y discursos de toda especie y de todas las épocas que agrupo bajo ese término en nombre de una comunidad de intereses o convergencias de efectos, lo que me parece más importante que su diversidad de aspecto" (8). Derrida, por su parte, utiliza el concepto de párergon, a través del recurso etimológico de carácter anfibológico que porta el prefijo para -con/contra-, para señalar la coexistencia metonímica del trazo en el adentro y el afuera del marco de la obra: "Queda un espacio por abrir para darle lugar a la verdad en pintura. Ni afuera ni adentro, se espacia sin dejarse encuadrar pero se mantiene fuera del cuadro. Trabaja, hace trabajar, deja trabajar el marco, le da trabajo (dejar, hacer y dar serán las palabras más incomprendidas por mí en este libro). El trazo mismo se atrae y retira de allí, se atrae y pasa por allí, por sí mismo. Se sitúa. Se sitúa entre la orla visible y el fantasma central desde el cual nosotros fascinamos" (25). Hillis Miller, por su parte, establece la relación parasitaria entre lector y texto a partir de la noción de hospedaje: el que acoge y el que es acogido. Finalmente, pertinentes dentro de este trabajo, son las palabras de Patricio Marchant: "En el cuadro de honor de los grandes hombres, la grandeza y el honor no lo ponen los hombres sino los cuadros. Un cuadro cuadra a un hombre; un hombre sin cuadro se descuadra" (21).
} 
el incumplimiento de la renovación literaria proclamada por el Grupo de los Diez: el fracaso de Santa Rosa, a unos pasos de la Alameda. También cabe mencionar la ocasión en que, en enero de 1963, Orlando Cabrera entrevista a Palazuelos y éste lo introduce con una respuesta:

[...] la literatura de la lengua española no había producido, desde $E l$ Quijote para adelante, algo que en prosa fuese realmente un aporte novelístico universal. Me encontré con el problema que, a mi juicio, se debía a que los escritores de habla española eran seguidores del estilo de generaciones anteriores. Sin embargo, en el plano meramente idiomático, llegaban a exquisiteces que daban la oportunidad de una crítica serena acerca del aporte documental de la época, lo más valioso que tiene, en definitiva, la novela. Entonces me di a la tarea de buscar un estilo, en el que el buen decir, el idioma mismo, tuvieran una importancia preponderante, pero que, en ningún momento, empañara lo que quería expresar. [...] Yo tuve la pretensión de crearlo. Pero, por suerte, la introspección y la autocrítica me mostraron que no iba a conseguirlo. Y me limité a revalidar uno: el de Teseo [...]: la novela tiene una forma musical, que es la sonata A. B. A. (Cit. en Cabrera s/n).

En julio de 1963 aparece en la Revista Ercilla una entrevista a Enrique Lafourcade realizada por el propio Palazuelos, titulada "Regresa capitán de polémica generación". En ella, el entrevistado contesta lo siguiente con respecto a quiénes son los más valiosos representantes de la generación del 50: “[...] Armando Cassigoli, María Elena Gertner, José Donoso, Pablo García, Enrique Lihn, Enrique Moleto, Claudio Giaconi, José Manuel Vergara, Jaime Laso, etc." (s/n). Palazuelos le pregunta si ha leído o escuchado otros nombres que vengan a renovar la literatura chilena. Lafourcade contesta: "Sí, algo leí en Ercilla sobre lo que Pepe Donoso llamó Novísima generación. El adjetivo 'novísima' es poco feliz. Es como una sociedad de escritores inéditos, condenada a muerte en sus propios estatutos y a medida que cumpla sus fines. (Discretas toses del redactor. Es preciso cambiar de tema para mantener la imparcialidad)" ( $\mathrm{s} / \mathrm{n}$ ). Por supuesto, Lafourcade no había leído nada de su entrevistador ni sabía que, de hecho, éste pertenecía a dicha generación condenada a muerte.

Tal vez la causa principal del largo silencio sobre Palazuelos se deba a que su escritura excedió los horizontes de expectativas de una crítica poco acostumbrada a la espesura de la autorreflexividad, a los gestos irreverentes y a la intermitencia de una tesitura inaudita. Por fortuna, aunque tal vez era solo cuestión de tiempo, en julio del año pasado Editorial Cuneta reeditó 
sus dos antinovelas prologadas por Roberto Gac (conocido también como Juan Almendro), autor radicado en Francia e íntimo amigo de Palazuelos ${ }^{3}$. Esta noticia exhibe, por una parte, el deseo de vitalizar a una figura eximia dentro de la literatura chilena $y$, por otra, la progresiva vigencia de una escritura intensa, desafiante y transgresora de los órdenes anquilosados de la tradición. Como en la película de Robert Bresson, el condenado a muerte está escapando de su destino.

\section{LA RECEPCIÓN DE LA ANTINOVELA PALAZUELIANA}

Aunque el problema de la determinación de los géneros literarios teóricos e históricos es de antigua data, éste parece extremarse a partir de las hibridaciones que genera la contemporaneidad. Las vanguardias artísticas se ubican, desde el principio, en un lugar donde ya habían instalado prefijadamente un discurso oposicional y rupturista con respecto a varios de los aspectos que adeudaba, y lo sigue haciendo, la modernidad. Así, la antipatía frente a la cultura heredada era manifestada repetidamente por medio de voces que, desde la tribuna, conminaban a ser antiburgués. No obstante, la paradoja reside en que dicha oposición se hacía desde la misma burguesía. Su propósito: enfrentar la tradición legada, pero parasitándola. La novela, evidentemente, constituye parte de esta tradición.

La crítica historiográfica ha ubicado los orígenes de la antinovela, dentro de la tradición hispánica, en Rayuela (1963) de Cortázar ${ }^{4}$. Sin embargo, tal como afirma Catalina Quesada, ya en el Quijote (1605) encontramos todos los juegos posibles con el género, sobre todo aquellos que permiten realizar una lectura metanovelesca ${ }^{5}$ de la obra de Cervantes: prólogos, dedicatorias,

3 Véanse El Bautismo (Barcelona: Montesinos, 1983) y El Sueño (Barcelona: Montesinos, 1985). Recientemente el autor ha reeditado sus textos a través de CreateSpace Independent Publishing Platform (Amazon) bajo los títulos de Antinovelas I y II.

"[Cortázar] se rebela fundamentalmente contra dos cosas: primero, contra una forma de narrar que corresponde a una falsa concepción de la realidad (esa forma que Cortázar llama Rollo Chino); y segundo, contra un lenguaje que masticado y rumiado hasta la excrecencia termina por desvirtuar la expresión literaria. Cortázar propone una novela abierta, hecha de fragmentos que, en su simultaneidad, darán una imagen auténtica de la realidad" (Alegría 245).

"La terminología con que la crítica se ha referido a las obras metaliterarias en el plano narrativo ha oscilado desde el término mismo de metanovela, hasta el de antinovela, 
explicitación de fuentes, inefabilidad ante la experiencia vivida en la Cueva de Montesinos, El Retablo de Maese Pedro, etc. Por ello, resulta del todo inadecuado plantear desde el binarismo una oposición al género tradicional, como lo hace, por ejemplo, Estébanez:

...la antinovela presenta una forma narrativa en gestación que invita al lector a la creatividad y que, al proponer la posibilidad de diferentes lecturas, revela en su autor la actitud de quien sólo sabe que no sabe nada y, negando todo dogmatismo, sólo acepta una escritura que revele su propia incertidumbre y su caminar entre tinieblas (Ana María Barrenechea 1988) (41).

Otro tipo de crítica, la textualista, ha alcanzado un relativo consenso al señalar que las narrativas vanguardistas latinoamericanas tienen como epónimo a Macedonio Fernández, pues éste subvierte el vínculo semiótico entre representación y presentación literarias, o entre demostración y mostración escritural. Pero no solo él, sino también Pablo Palacio, Felisberto Hernández, Juan Emar, Oswald y Mario de Andrade, entre muchos otros. A mi juicio, Palazuelos se ubica en el extremo de los procedimientos vanguardistas en la medida en que sus textos se constituyen a partir de operaciones de disección que, en última instancia, abren y fragmentan las posibilidades de sentido, como se verá más adelante.

La obra de Palazuelos, es decir, la suma de sus textos intencionados discursivamente, generó convergencias y divergencias en cuanto a su recepción crítica: se deliberó en los medios escritos. Para algunos, se trataba de un escritor novísimo (vanguardista) que se oponía a las generaciones criollista y del 50, a través de una singular técnica de escritura. Para otros, en cambio, su obra expresaba una suerte de neoexistencialismo juvenil que hacía prometedora la propuesta, aunque adolecía tanto de problemas de forma como de fondo.

Filebo, seudónimo de Luis Sánchez Latorre, crítico oficial de Las Últimas Noticias, escribió un testimonio sobre Palazuelos y los novísimos, liderados por éste, en el cual cuestionaba su carácter renovador o rupturista con respecto

pasando por otros como introverted novel (novela introvertida), irrealism (irrealismo), surfiction ("sobreficción"), self-beggetting novel (novela que se construye a sí misma), fabulation ("fabulación"), metafictional mode (modo metafictivo), incluso narcissistic narrrative..." (Quesada 26). 
a la generación precedente ${ }^{6}$. Ricardo Latcham, por otra parte, busca indagar en los orígenes de esta novísima escritura que estarían, según él, en el ámbito universitario y en "un sentido rebelde frente a la vida, que no siempre posee una raíz política". En lo que respecta a la escritura palazueliana, Latcham señala:

...la prosa es correcta, pero entrecortada y, en ocasiones, el jadeo persigue al lector con un ritmo pesado que después se libera, a medida que se capta el hilo psicológico de un asunto enquistado en la rebeldía juvenil [...]. Sería tarea fácil descubrir fallas y pedanterías conceptuadas en Según el orden del tiempo, pero es más útil comprender la intención del autor y su emplazamiento vital a un orden estimado falso y a unos moldes dominados por lo aparencial. La acción se desdobla y rompe los montajes rutinarios con un estimulante dinamismo $(\mathrm{s} / \mathrm{n})$.

Lo que el crítico destaca, el jadeo persecutor y el dinamismo estimulante, puede percibirse ya desde el comienzo de la narración de Según el orden del tiempo:

Tarde roja. De primavera. Pero no es primavera.

Es verano.

No tendría ninguna importancia la estación si no hiciese tanto calor. Rojo eléctrico; bello pero demasiado brillante. Como todo lo que es bello para todos. Desaparece el contraste. Pura evidencia.

Debería salir a la calle. Sin embargo, permaneceré donde estoy ${ }^{7}$. Debo hacer algo con mi tiempo. Así, encerrado dentro de mí, hace que me sienta como una jaula, estrellándose incesantemente contra todo mi

\footnotetext{
"En literatura, la generación del 1950 se componía de jóvenes nacidos hacia los años 30. En 1960, el superjoven novelista Juan Agustín Palazuelos, aburrido de la cantinela del 50, inventó la aparición de los Novísimos. Él mismo se etiquetó como novísimo [...] creo que la existencia de los novísimos no pasó de constituir un simple volador de luces. Los llamados novísimos se distinguían de los del 50 sólo por la edad. Eran más jóvenes. No había en ellos un gran cambio de temática, escenario o de estilo. Por lo demás, tengo la certeza de que Wacquez no tomó nunca en serio la idea de registrar en la palabra una doctrina" (Filebo 47).

Compárese con la espera inútil de Vladimir y Estragón en Esperando a Godot (1952) de Samuel Beckett. Se trataría, en ambos textos, de un funcionamiento contrateleológico por cuanto la postergación o diferimiento del cumplimiento articula sus narraciones. En este sentido, también se relacionaría con el cuento "Una llamada a Patricia" de un joven Palazuelos, pero publicado en 1963, en donde el narrador no se decide nunca a llamar a su amiga porque la cotidianeidad lo interfiere permanentemente.
} 
organismo. Es demasiado torpe para huir solo. Debo abrir yo mismo la puerta de la prisión. He perdido la llave (23).

Esta dicción intermitente es bien recibida por la perspectiva de Ricardo Gelcic, quien considera a Palazuelos como la viva renovación de la literatura chilena ${ }^{8}$. El crítico recalca, además, la brecha temática que separa a una generación de la otra: mientras que la del 50 prestaba atención a temas relacionados con la vida urbana, la nueva generación desarrolló una escritura más introspectiva que reflexionaba sobre su propia producción escritural:

He comenzado a disertar sobre quiromancia. Creciente interés de todo el mundo. Menos mío. Me aburro con mis propias palabras. Las rebusco. Impecable lenguaje. Sintonizo bien hoy día. Me escucho perfectamente. No debo perderme el final sicalíptico 9 . Le da tono confidencial y las gentes tosen un poco (Palazuelos, Según el orden del tiempo 52).

Un planteamiento similar al de Gelcic es el de Roberto Briseño, quien declara que Según el orden del tiempo (1962) se aleja de la tradición mediante una narrativa desprovista "de finas filigranas poéticas, en [la] que la frase corta, pausada por puntos, adquiere una propia y desconocida dimensión”. Así, la novela de Palazuelos habría "desbordado las fronteras de su propio destino, aproximándose en cierta medida a las formas de un testimonio existencial" (s/n). Por su parte, Gonzalo Drago, desde Angol, comenta con gran desconcierto la primera novela de Palazuelos:

...esta novela es desconcertante y, podríamos afirmar sin temor a equivocarnos, desarticulada, escrita en un estilo telegráfico, si podemos definir en esa forma su lenguaje de frases cortas, consecuencias novedosas, que terminan por colocarnos en un plano de franca

\footnotetext{
“...el placer sensorial de la experiencia estética, una constante reflexividad que va estructurando la acción en un sostenido preguntar y la actitud ante la mujer, vivida como sensualidad y emoción de amor. La primera, plenamente gustada; a la inversa, siempre fallida, la segunda. Frustrada, en el amor de la infancia, no lograda en su realización plenaria con Soledad, voluntariamente eludida con Hexe en la anécdota que pone término al libro dejando al protagonista en la misma incertidumbre del comienzo, si bien esta vez, con una ganada responsabilidad" (Gelcic s/n).

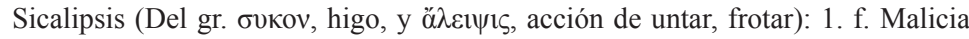
sexual, picardía erótica (DRAE).
} 
admiración hacia su autor [...], [quien] posee una sólida cultura humanística que lo coloca en ventajosas condiciones para elaborar su novela con raíces mitológicas, un moderno método novelístico que sorprende gratamente al lector más avezado (...) Palazuelos sin esfuerzo aparente, nos ha entregado una novela meritoria, a veces desconcertante, elaborada con gran sentido de responsabilidad literaria $(\mathrm{s} / \mathrm{n})$.

La rebeldía de Palazuelos se transforma en una promesa dentro de la literatura chilena de esos años. Hernán del Solar ${ }^{10}$ y Ester Matte Alessandri ${ }^{11}$ van a coincidir en el carácter transgresor de Palazuelos frente a la generación anterior, que se materializa en una búsqueda, monólogo o "hallazgo de sí mismo" e indicarán como promisorio y positivo lo que otros críticos habrían de censurar: la dificultad de la lectura ${ }^{12}$ de fragmentos como los siguientes:

10 "Se trata de un novelista destinado a señorear el arte en que se inicia, si desecha halagos y apresuramientos, convencido que es un arte difícil y exigente [...]. Irá contra los viejos inmediatos, es decir, los del 50. Ya está aparte, no los mira, y es posible y probable que no los entienda. ¿Qué han venido a hacer ustedes -les podría decir en su fuero interno-, que ambicionaron derribarlo todo y tuvieron que construir ruinas artificiales para creer cumplida su misión? Y si se examina un poco este juicio, encontrará razones para afirmarlo [...] El mundo que le dan, el de sus mayores, es un recinto hermético por el que van y vienen los enmascarados, exteriormente pintorescos, simples comparsas que juegan a darle a la vida un sentido. El personaje se siente desterrado en este mundo de contratiempos, de ataduras, de resonancias de un mundo perdido y que se debe buscar [...] Todo lo mira con ojos nuevos, y el espectáculo es siempre el mismo, de engaños, de laberinto sin salida, pero que alguna tiene, no obstante, y lo que importa es encontrar el método para el hallazgo de sí mismo, de los demás, de la vida como se quiere tenerla" (Del Solar s/n).

11 “... Según el orden del tiempo ha tenido una de las más entusiastas acogidas de la crítica. El libro, sin embargo, no es de fácil lectura. Hay una forma novedosa, dinámica, para exponer las ideas y hacer evocaciones a la que el lector no está acostumbrado. He ahí parte de su mérito. Hay varios planos que alteran dando una sensación de caos, que corresponde a una realidad subjetiva más honda y profunda que el lógico desarrollo de episodios ordenados ficticiamente [...] Esta valiente posición para afrontar la soledad de la propia búsqueda, revela una mentalidad directa, vital, donde el análisis busca interpretar la vida, pero no la entiende ni la frustra [...] El individuo no se sujeta a normas, sino que busca su propio camino, dificultosamente, en un permanente monólogo consigo mismo" (Matte 263-264).

12 En una nota anónima aparecida el 20 de abril de 1969 en El Diario Ilustrado se dice, a propósito de la segunda edición de Según el orden del tiempo (1968), que "la obra es un tanto sofisticada, la acción se desenvuelve en un ámbito literaturizante, en donde los personajes conversan haciendo amplia exhibición de sus conocimientos en diversas materias y muestran su erudición; pero, a mi parecer, había una estructura novelística endeble". 
Verano...

Ahora es invierno.

Amarillo...

Ahora ceniza.

Tonos brillantes y enceguecedores...

Ahora tonos opacos que apaciguan. (Es mejor, no hay posibilidad de deslumbrarse.)

Un calor sofocante...

Ahora frío en todo mi cuerpo. (No obstante, la vivencia me hace transpirar por dentro. El sudor corre por el revés de mi piel, hiriendo con su caudal salobre cada uno de mis nervios. Por fuera mi piel permanece reseca).

Tengo frío y calor ${ }^{13}$ (Palazuelos, Según el orden del tiempo 124).

Adán. Nada. Adán es nada. Eva es reversible. Ave. Eva volando. Era mucho más fácil no comerse la manzana. Era más cómodo. Pero si se volaba un poco se podía coger la fruta y dársela a la nada. Para que fuera algo. De la nada a la hombría ${ }^{14}(108)$.

Ante la aparición de la segunda edición de Según el orden del tiempo, M. C. G. advierte la afinidad de su escritura con la de Gustavo Sainz, exponente de la "literatura de la onda" mexicana. Este crítico destaca de su narrativa los encadenamientos paradójicos, el "ultra sintetismo" con que se representan las imágenes y el espesor que adquiere progresivamente ${ }^{15}$.

13 El permanente oxímoron sitúa el fragmento en el plano barroco, del claroscuro, pero además refuerza la oposición temporal que articula toda la novela (pasado y presente). Lo irrecuperable frente al futuro incierto aparece en el motivo barroco de la ceniza, como el soneto de Góngora "Mientras por competir con tu cabello" (1582, soneto 24 según el ordenamiento cronológico): "antes que lo que fue en tu edad dorada/ oro, lilio, clavel, cristal luciente,/ no solo en plata o viola troncada/ se vuelva, mas tú y ello juntamente/ en tierra, en humo, en polvo, en sombra, en nada".

14 En los consabidos anagramas que vinculan a Adán con Nada y luego Eva como el ave que coge la manzana y la lleva hacia la nada, está funcionando la traducción que hace Palazuelos de aperion: inmediatamente después de la frase "de la nada a la hombría", Palazuelos pone la frase con los términos griegos: "Desde el apeiron a la andreia" (en la edición de Cuneta hay, al parecer, una confusión entre $r$ y $f$ por semejanza visual: $\rho, \phi$ ). Sin embargo, el sentido de apeiron en Anaximandro se vincula a una arché muy particular, en tanto se trata de lo indefinido, infinito e imperecedero como principio u origen de todo cuanto existe.

15 "Salto continuo con el punto seguido cada cinco o seis palabras, sin tomar no obstante ese ritmo de gotera, tan precario en otros escritores. Definición de cosas o estados 
Palazuelos promete, entonces, y habrá que esperar el desarrollo de su escritura para evaluar los alcances poéticos y estéticos de su propuesta. Sin embargo, la desilusión y frustración parecen animar de sentido a la crítica que se le hace a su segunda novela, Muy temprano para Santiago (1965), tanto desde el punto de vista formal como de su contenido. Uno de sus críticos más conservadores planteará que

[su] trama marcha por varios caminos paralelos, sin seguir el orden del tiempo. A un paso del epílogo, la narración empieza con la misa de réquiem de una muchacha, salta hacia atrás y continúa avanzando y retrocediendo por múltiples hilos hasta llegar a mostrar el cuadro completo. Es un triste cuadro, hecho de frustraciones y desorientación: una juventud que se embriaga y se encama, habla trivialidades, huye de sí misma, se enfrenta sin comprensión posible con unos adultos esclerotizados por principios que declaman con energía, pero no saben vivir (G.B. 34-35).

Lo que escandaliza a este crítico anónimo son pasajes como estos, cargados de sátiras y desbordes narrativos:

No confundas. ¡Eso fue una orgía... y sanseacabó! ¡Dios mío, estos niños están habitando la Ciudad del Demonio!... ¡Ayúdalos, Señor, a que aprendan a distinguir Tu Ciudad, de La Ciudad del Mundo! ¿Que por lo menos sepan que Santiago ya es la Ciudad del Demonio! (Palazuelos, Muy temprano para Santiago 238)

Sin embargo, no podré saber jamás cómo es su pena. A qué huele. Qué partes de su organismo hiere más. [...] Porque en la historia de mis minutos ocupa el Siglo de Oro, el tiempo de lo que quiero olvidar por ahora. Pienso en el humor como algo imposible e inadecuado. Sin embargo, sé que la tristeza es siniestra y debo huir de ella. No hay sitio donde refugiarse. ¿Dónde comenzará la risa? Ni en la boca ni

de cosas, por encadenamiento, con frecuencia paradójico, o recuerdos reducidos a uno o dos vocablos, especie de ultra sintetismo que, sin embargo, parece inundar de imágenes y de vitalidad los pasajes. Este estilo, sin duda eficacísimo en determinados aconteceres del tiempo de los personajes y determinados caracteres de los mismos, cuando llena un libro cansa fatalmente y va perdiendo fuerza de gravedad, como si dijéramos. Palazuelos parece intuirlo y así hacia el final densifica los períodos, prolonga el recorrido de la imagen ante el que lee y el viviendo de los seres novelescos [...]. El libro consigue ser en legítima medida un cuerpo cuyas partes se corresponden en un enlazamiento fácil y en un tono central que lo sostiene e identifica" (M.C.G. s/n). 
en la garganta. Ni siquiera en los ojos. (En ese sitio habría que herir al enemigo). Quizás sea el mismo lugar de la tristeza. Cada imagen de presente tuvo su origen en el pasado: ahora me ocurre que estoy frente a un espejo que sólo refleja su metálica profundidad (silencio mercurial). La oportunidad para ver lo que ocurriría se presentó mil veces... (61).

Con un tono cercano a G. B., la crítica de Juan Tejeda despedaza los miembros separados de Muy temprano para Santiago:

Cada trozo de este libro está bien escrito. Pero el conjunto no está armado. O está armado de un modo tal que no se hace accesible al lector [...]. Es una tela bien hecha, sin forma ni estructura, que podría alargarse hasta el infinito, siempre monótonamente perfecta [...] Quien la lea con afán crítico sufrirá muchísimo, porque tendrá que seguir adelante y tratará de explicarse a dónde va la intención del autor [...] Porque a través de la manera de desenvolverse de Palazuelos, se palpa algo, algo no muy definido aún, algo como un instinto de mostrar cierta simultaneidad de los recuerdos en la conciencia, que no distingue entre el ayer y el hoy. Y, también, algo como un querer mostrar no ya a los personajes diferenciados, si no [sic] como formando parte de un mismo monstruo colectivo, como si cada cual fuese un poco los otros, confundidos en un mismo destino que los ha juntado más o menos arbitrariamente, más, más que menos [...) Pues el autor se encarga de poner todos los obstáculos para la comprensión fácil ( $\mathrm{s} / \mathrm{n})$.

Tejeda condena de Palazuelos lo que denomina como siete pecados capitales ${ }^{16}$, es decir, no entiende sus principales virtudes: la espacialización del tiempo, la

16 " $1{ }^{\circ}$ Los tiempos. [...] La habilidad para entretejer diversos tiempos siguiendo más bien una lógica del sentimiento, aparece trocada aquí por algo que parece pura arbitrariedad, lo que no hace accesible por tanto la obra. [...] Aquí, repetimos, no hay suspenso. Ni siquiera esa curiosidad que forma parte del suspenso, porque todo lo que pasa en la novela (o se comenta como pasado) podría seguir cualquier otro rumbo: no se ve el hilo conductor. $2^{\circ} \mathrm{La}$ pedantería. Grave obstáculo, porque exige al lector ser casi un erudito (...) ¡Qué diferencia con las grandes obras literarias con el fluir de la sencillez grandiosa de las parábolas de Cristo o las películas de Chaplín. $3^{\circ}$ La grosería [...] o las expresiones burdas no sólo las pone en boca de los personajes, sino también las profiere el narrador, lo que nos parece una novedad sin ningún interés. $4^{\circ}$ Muchas reflexiones, demasiadas reflexiones, algunas o todas muy inteligentes, pero excesivas en número y dentro de una ambivalencia insolucionable. $5^{\circ}[\ldots]$ 
enciclopedia puesta en circulación en el texto, la frustración de la perlocutividad, el coloquialismo, la autorreflexividad, el saber del no saber, la narración in extremis, la escritura como enigma cifrado y la frustración metaficcional, cuestiones perceptibles en lexias como esta:

Addenda de algunas páginas no curriculares del cuadernos de Física mencionado. 'Ley de Gay-Lussac' ${ }^{17}$. El nombre de esta ley tiene su origen... (Nota actual: aquí la letra se hace ininteligible y el texto de la formulación no existe. Hay algunos dibujos caóticos; luego un espacio en blanco, hasta que nos topamos con el siguiente texto):

\section{EXPERIMENTO PARTICULAR}

Se toma una hormiga grande. (Las chicas no sirven porque resisten muy poco). Luego se dobla una hoja de papel en tres (longitudinalmente), y se procede a golpear sin mucha energía al insecto. Se verá, entonces, que la hormiga comienza a moverse vertiginosamente. Sin embargo, después de unos tres o cuatro golpes detiene sus excéntricas carreras y comienza a girar en torno a una de sus patas traseras. Comienza, digamos a 'girar en sí misma'. Es el momento de tomar una lupa y observarla en tamaño aumentado. Su cuerpo se mueve convulsivamente. El abdomen se hincha y se deshincha, pareciendo próximo a explotar. Su cintura se arquea y congestiona, su cabeza gira sin sentido, de derecha a izquierda y viceversa. Con sus patitas delanteras trata de componerse las antenas, que parecen averiadas (es probable que a causa de los golpes). En cuanto a sus ojos, muy poco o nada puede averiguarse, porque, por desgracia, no se tuvo la precaución de observarlos antes de los azotes. De su boca parece salir un líquido que ella utiliza en la reparación de dichas antenas. Uno piensa que podría tratarse de sus propios jugos vitales o de sus vísceras internas demolidas por los golpes. La idea es asquerosa. Se rechaza, además, por poco probable, dada la poca intensidad

Una sensación espantosa en torno de no se sabe qué [...]. $6^{\circ}$ Clave. [...] Novela escrita de atrás para adelante, sólo puede interesar a lectores de atrás para adelante. $7^{\circ}$ Literaturitis. Es tan monstruosa esta enfermedad, que ella puede verse en la forma en que el autor firma (...) Creemos que formalmente que Juan-Agustín Palazuelos no hará accesible al lector lo que quiere darle, porque le exige demasiado (...) Nos parece una obra bien frustrada hecha por un literato perfecto" (Tejeda $\mathrm{s} / \mathrm{n}$ ).

17 Tanto la Primera Ley de Gay-Lussac (o de Charles) como la segunda, relacionan el volumen y la temperatura de una cierta cantidad de gas ideal, mantenida a una presión constante, mediante una constante de proporcionalidad directa. En el pasaje tiene relación irónica con la temperatura que alcanza el cuerpo torturado de la hormiga. 
del estímulo. ¿Pensará la hormiga en esos instantes? ¿O en otros? ¿Tratará de comunicarse con sus congéneres? Poco a poco se va quedando quieta. Se observa, especialmente, que está entregada a la reparación de sus antenas. Ya su abdomen no palpita en forma alocada. /Entonces ha llegado el momento de concentrar sobre la tranquila hormiga los rayos de sol, a través de la lupa. (El sol es fuente de vida). Al comienzo, la hormiga parece contenta, pero a medida que la concentración de la luz se hace más perfecta y violenta, la hormiga recupera su capacidad de movilización. Corre, corre desenfrenada, hasta que por un error, o por un deseo incontrolado (pero compulsivo) de ver los últimos efectos de la luz solar, concentramos al máximo el foco. La hormiga, detenida en plena carrera hacia unos de los bordes de nuestro pupitre, se convierte en una tenue columnita de humo azulado. /Después soplamos sobre la superficie de la mesa de trabajo. El viento se lleva el oscuro caparazón, ya vacío. Sobre la mesa queda una leve huella del acto incineratorio. Basta pasar la yema del dedo anular izquierdo para borrar los rastros...

(Después continúan, hasta el final de la página, los dibujos caóticos. En la hoja siguiente se halla transcrita, con perfecta letra y extremada pulcritud, la Primera Ley de Gay-Lussac). Cabe destacar que la palabra 'Patricia' puede distinguirse de entre los jeroglíficos mencionados" (116-118).

En resumen, la escritura de Palazuelos exhibe una promesa que difirió el cumplimiento de las expectativas que la crítica alzó con respecto a él, dedicándose en cambio a una escritura malograda, confusa, monstruosa, desmembrada. De allí la necesidad de hablar e instalar el concepto de disjecta membra.

\section{DISJECTA MEMBRA: LA ESCRITURA MALOGRADA}

Es usual encontrar este concepto en la escritura académica portuguesa, española y anglosajona para referir elementos poéticos que describen la literatura clásica latina. Así, Horacio dice en la cuarta sátira del libro primero:

En las sátiras que yo escribo ahora, en las que compuso Lucilio antiguamente, al quitar el tiempo y la medida, y trastornar el orden de los vocablos, poniendo al principio los últimos, no se encuentra lo que en estos versos, aunque los deshagas: "Después de que la discordia rencorosa / Rompió la puerta y los quicios de la guerra..." 
Aquí aún se ven los miembros despedazados del poeta. Y basta por hoy. En otra ocasión discutiremos si estas composiciones merecen el dictado de poemas; ahora veamos si es o no justo el odio que profesas a la sátira (24).

El poetólogo cita a Lucilio, autor de sátiras romanas, a quien él mismo señala como "el padre de este género histórico", pero lo critica; sobre todo, porque no usa un lenguaje elevado, sino el sermo vulgaris, es decir, el habla de la calle. Más adelante, establece una comparación entre éste y Ennio, quien, además de ser un poeta satírico, es precursor de la poesía épica latina. De este modo, Horacio entiende que el "buen poeta" no es quien emplea versos "solutos", esto es, sin métrica y cercanos a la prosa, aunque los desarticule, sino aquel que se desmiembra en ellos.

Según Soledad Chávez, Horacio parece advertir en los hipérbatos esa condición propicia para el funcionamiento de los disjecta membra donde, a pesar de la desarticulación, se exhibe el virtuosismo del poeta verdadero. Sin embargo, la irrupción de aquellos es producto de la escritura latinizante del siglo XV, por lo que habría que considerarlos como protohipérbatos. Un ejemplo de este recorrido, más tarde, lo constituye la escritura del moralista y humanista español Antonio de Guevara durante el siglo XVI ${ }^{18}$.

Precursor de todos, entonces, la influencia de Guevara se extiende hasta los dominios de Cervantes, Góngora y Quevedo, solo para señalar algunas figuras ejemplares. Es interesante que Castro instale también como expresión de la descomposición, los paralelismos y las antítesis todavía en el plano sintagmático de la lengua. Yo agregaría otras figuras y recursos dentro del funcionamiento de la desintegración textual: oxímoros, símiles, anáforas, aliteraciones, catáforas, elipsis, deixis, anadiplosis, pleonasmos, asíndeton, polisíndeton, etc.

18 Américo Castro afirma con respecto a él: “....en el alma de Guevara los componentes de esa forma de vida - caballería, saber de cosas humanas, religión, mundanidad-se encuentran desintegrados y sin fusión posible: «prometo como caballero, juro como cristiano» (o al contrario). Su ánimo está poblado de «disjecta membra». No pudiendo vivir en el tráfago del siglo, su ímpetu enorme e insatisfecho se vuelca en la expresión, en trocitos fragmentados y menudos, o en frases contrapuestas, paralela o antitéticamente. Su genialidad consistió en representar su vivir auténtico en un estilo no menos auténtico, labrado a su medida, no falso ni engañoso, puesto que virtualmente es lo que Guevara es, un intento de existir buscando sustitutivos a sueños de gloria malograda, y reflejando a la vez las fracturas insondables de su alma. De ahí que le embriague la oratoria, arte espectacular y muy para vanidosos" (50). 
Los usos metafóricos del concepto disjecta membra traicionan las recomendaciones de Horacio y la verificación que realiza Castro en la escritura de Guevara, ya que la teratología barroca, según Aullón de Haro, se asimila más a un conjunto de disjecta membra que a un mapa ordenado de representación del conocimiento.

Pero no será hasta la publicación de Poesía y estilo de Pablo Neruda por Amado Alonso (1941) cuando sea este concepto el que sirva para enmarcar el tránsito que ha experimentado el poeta desde Crepusculario (1923) hasta las dos primeras Residencias (1925-1935). La imagen es incapaz ahora, dice el estilista, de referir el sentimiento intuido. En otro lugar he advertido los problemas que genera esta lectura de Alonso ${ }^{19}$, pues le pide organicidad a una obra que va sistemáticamente contra ella, a través de oxímoros, antítesis, anáforas, sinécdoques, etc. Gutiérrez Carbajo señala que el gran hispanista lee estos textos a partir del criterio de la deformación, desposesión y destrucción como expresión de una desintegración epocal que se corresponde con el concepto de membra disjecta. Éste se carga ahora de negatividad, pues expresa decadencia atribuida a los marcos expresionistas y existencialistas de lectura: Hausser y Ortega, por ejemplo.

López Martínez, quien sigue a Alonso en la lectura de Residencia en la Tierra, señala con respecto al poema "El desenterrado" que "a pesar del ambiente funerario pleno de putrefacción, de membra disjecta tan de gusto barroco y surrealista, a pesar de la desintegración que todo corroe, la figura del Conde no es rechazada" (101). Se historiza, entonces, el concepto y se establece una relación -no extraña, sin embargo- entre el barroco y las vanguardias (surrealismo, dadaísmo, cubismo, etc.). De esta manera, para Sebreli ${ }^{20}$, este recurso expresa exageración, inconmensurabilidad, frenesí, delirio, desorden, deformidad, arbitrariedad, artificio, rareza, extravagancia, dificultad, confusión, oscuridad e incomprensión.

Por otra parte, el concepto aparece instalado en los diccionarios de inglés, y no en los nuestros, ni siquiera en los teóricos, bajo tres entradas distintas al sustantivo plural: disyunción, separación, desconexión; desorden, trastorno,

$19 \quad$ Véase Wallace, David. “(Des)construyendo un sistema. Notas sobre Sistema sombrío de Pablo Neruda". Anuario de Postgrado No3. Santiago: Escuela de Postgrado, Facultad de Filosofía y Humanidades, Universidad de Chile, 1999. pp. 461-470.

$20 \quad$ "El recurso barroco de los disjecta membra está en el poema surrealista, en el object trouvé y en el cuadro cubista" (Sebreli 24). 
irregularidad, anomalía; y, dispersión, divergencia, difusión. Es en este sentido que propongo una lectura para los textos de Juan Agustín Palazuelos como composición y descomposición monadológica ${ }^{21}$ de la escritura, es decir, de los lexemas que irradian la superficie textual. La revitalización, dentro de la tradición hispánica, del legado de Guevara:

El que Guevara se contemple a sí mismo desde tan cerca, presta un tono especial a los artificios de su retórica, que no enlaza con temas objetivos directamente; lo que se siente en Guevara es la conciencia del autor de estar escribiendo, algo así como si estuviera mirándose en el espejo de sus palabras y frases (Castro 52).

En conclusión, se trata de una escritura intransitiva (Blanchot), autorreflexiva (Barthes), abismada (Dällenbach) y gestual (Agamben) que no hace de la representación un objeto, sino que se presenta en el proceso de composición y descomposición escritural a través de su figuración material dentro del texto, esto es, en su trama y urdimbre. Un claro ejemplo de lo anterior es La Visitadora (1964), breve antinovela atravesada de principio a fin por una espesura especular que multiplica las aberturas de sentido:

BASTANTE perdido en el espanto de una verdad dicha a medias. Vigorosa por ello. Se medita demasiado cuando es preciso decir sólo una parte.

Horror por el silencio obligado.

Poner las cosas en orden.

Primer problema: ¿Cuántas moscas caben entre los dientes de un cocodrilo macho?

Solución: Depende del tamaño de las moscas; del hueco entre los dientes (del cocodrilo, se entiende); del número de ellos (los dientes). En cifras $=$ equis moscas.

21 "67. Cada porción de la materia puede ser concebida como un jardín lleno de plantas y como un estanque lleno de peces. Pero cada rama de la planta, cada miembro del animal, cada gota de sus humores, es también un jardín o un estanque similar. 68. Y aunque la tierra y el aire interpuestos entre las plantas del jardín, o el agua interpuesta entre los peces del estanque, no sean en absoluto planta ni pez, sin embargo los contienen también pero muy a menudo con una sutileza que es para nosotros imperceptible.(...) 70. Según esto vemos, que cada cuerpo viviente tiene una entelequia que en el animal es el alma; pero los miembros de ese cuerpo viviente están llenos de otros seres vivientes, plantas, animales, cada uno de los cuales tiene también su entelequia o su alma dominante" (Leibniz 621). 
¡Gracias!

Abandonemos la ciencia y el método para dar con eso. Inventemos un lenguaje más oscuro (más oscuro que el de las meras palabras) (230).

\section{EL CORPUS TRASTORNADO}

Tal vez el tópico que refiere mejor el concepto de desorden, irregularidad y anomalía del cuerpo, que leo desde la metonimia y no desde la metáfora, es decir, como texto y no discurso, es lo grotesco, que adquiere un estatuto retórico relevante a partir de la lectura que hace el romanticismo de la Edad Media $^{22}$. Sus colecciones se organizan dentro de un repertorio estratégico que transforma al gótico en un referente estético para la escritura: las catedrales de Palazuelos.

Según Courtine, esas ficciones grotescas se construían mediante imágenes, no siendo necesaria su aparición real para la proclamación de las mismas: "en la literatura popular, es la ficción la que, normalmente, precede o incluso produce la realidad" (366). En la ciudad antigua, la mirada se exponía al espectáculo de la deformidad de tal forma que, en cuanto se extendía la noticia de un nacimiento monstruoso, el pueblo acudía rápido, transformando el domicilio donde se ha producido el acontecimiento en teatro circunstancial. La deformidad se teatralizaba: "El monstruo es entonces objeto de espectáculo, y da lugar a un comercio" (Courtine 367). Esa era la experiencia sobre la monstruosidad, una curiosidad social que se convertía en el espectáculo de una catástrofe capaz de desestabilizar la mirada y de interrumpir el discurso en cuanto irrepresentabilidad de la "aparición de lo inhumano, de la negación del hombre en el espectáculo del hombre vivo" (Courtine 367). Sin embargo, para el autor, no ocurre lo mismo con lo monstruoso. En aquella categoría ya no hay presencia ni cuerpo, sino signos y discursos: se trata de una construcción sistemática de imágenes, objetos de consumo y de circulación, lo imaginario que supuestamente transcribe lo irrepresentable.

De esta concepción resulta fácil imaginar el auge de una fábrica de lo monstruoso, donde la invención de este tipo de cuerpo obedecía quizás a su 
principio más característico: la hibridación ${ }^{23}$. Para Courtine, era necesario que dentro del monstruo hubiera también un hombre, donde, además, si examinan con atención aquellas imágenes, "se adivinan reglas de reparto, de distribución, de imbricación de lo humano y de lo bestial en la representación monstruosa" (368). La bestialidad, en este sentido, se tocaba usualmente con la periferia del cuerpo y con el exceso numérico de miembros, a la vez que desfiguración era solo superficial, estableciendo una extraña paradoja: "un orden casi mecánico reina sobre las figuras del desorden corporal extremo" (370).

Así, de la forma en que miremos el cuerpo del monstruo, éste también representa imágenes de orden y de razón, una racionalización que tiende a ocultar la relación metonímica expresada en el cuerpo protuberante del carnaval y que tendía a desestabilizar el orden por un tiempo en el centro de la ciudad medieval. Puede ser esto, según Courtine, "una etapa esencial en el largo rechazo histórico de lo que, en el cuerpo monstruoso, demuestra que lo inhumano no puede ser ni asimilado, ni representado" (371).

La monstruosidad, sin embargo, no puede ser comprendida más adelante sin una referencia a las prácticas médicas y de normalización del cuerpo que se suscitaron a partir de la operación disectiva por parte de Vesalio. Esto, que para Mandressi puede considerarse como una invención, surgió en un momento como una respuesta adecuada a la necesidad de perfeccionar un nuevo saber sobre el cuerpo. En este sentido, el saber anatómico estuvo asociado desde un principio a la observación: los sentidos de la vista y del tacto actuaban como método de construcción de una verdad sobre un cuerpo específico: el cuerpo muerto. Y así como la monstruosidad se teatralizó en la Edad Media, entrado el Renacimiento y en dirección a una modernidad, se diseñaron formas de exposición del cadáver, entre las que se cuenta, además del anfiteatro ${ }^{24}$, el libro, donde, "en cada lugar del texto, lo que quedaba por leer correspondía a lo que quedaba del cadáver sobre la mesa de disección. El orden de los libros también era un orden de destrucción del cuerpo" (Mandressi 314). La anatomía, de esta manera, dibuja su objeto y, en un intento de fragmentar la materia corporal cada vez más finamente, se llega a partes cuya segmentación

23 "El conjunto dialoga entre opciones que se recombinan o apartan. Se confirma un "aire del tiempo" en el juego de las diferencias. Hago una prueba de contacto, un continuo monstruoso de lectura, sin autoridad, por más que resulte estimulante" (Echavarren et al. 9).

$24 \quad$ Véase el espectáculo del supliciado en Farabeuf (1965) de Salvador Elizondo. 
no produce ya diferencias, sino igualdades, desde donde también se puede decir que el discurso médico y anatómico no invoca la correlación entre el macrocosmos y microcosmos a título de simple metáfora.

Con todo, las teorías unitarias de las correspondencias cósmicas y los humores fueron destronadas cuando llegó el tiempo de la anatomía y de la teoría fibrilar, que puso término a un largo ciclo rematado por el triunfo epistemológico del principio de fragmentación. Lo que hay detrás de las múltiples figuras de lo anormal es, para Courtine, siguiendo a Foucault, la emergencia y extensión de un poder de normalización, la que se realizó a través "de un conjunto de dispositivos de exhibición de su contrario, de puesta en escena de su imagen invertida" (206). De esta manera, se debe establecer que la monstruosidad no se sitúa tanto en el cuerpo del otro como en la mirada que lo contempla. Apartada del cuerpo, la deformidad es un asunto meramente discursivo que tiende a estigmatizar a través de la metáfora cualquier rasgo minoritario. Asimismo, según el autor,

[1]as sociedades democráticas han querido convertir el cuerpo anormal en cuerpo corriente. [...]. La anomalía corporal, despojada de la rareza que la había mantenido tanto tiempo apartada, [viene] a diseminarse en el archipiélago infinito de 'diferencias'. Pues ése es precisamente el término escogido por las sociedades democráticas para proclamar - por medio de un rechazo deliberado de la mirada por parte de la razón- la igualdad entre los cuerpos (255).

De esta forma, la suspensión de lo deforme en la proliferación de las diferencias la sitúa junto a un cúmulo de signos indistintos, que anula la misma diferencia. Por consiguiente, la igualdad se transforma en uniformidad que, nuevamente, no dignifica el cuerpo anormal, sino que lo diluye junto a la serie de representaciones que de él se hacen por medio de una violencia metafórica, esto es, homogeneizadora.

En definitiva, ante tal uniformización, solo queda buscar un cuerpo capaz de revertir la homogeneidad a través de metonimias que ubiquen las ausencias junto a las presencias. Ese cuerpo puede ser el cuerpo sin órganos propuesto por Deleuze y Guattari, un cuerpo ubicado en el puro presente del devenir que desestabiliza cualquier orden jerárquico y normalizante que trate de imponérsele. Un cuerpo libre de significados anteriores a él y cercano solo al programa o la experimentación; un agenciamiento intensivo, un puro deseo -no placer- desterritorializado, donde lo único que cuenta es el flujo, la pura inmanencia. Mesetas comunicantes que anulan el organismo en 
cuanto orden jerárquico y simbólico, erigiendo al cuerpo en tanto cuerpo y nada más. Un cuerpo cercano al corpus de Nancy, concebido en su extensión (meseta), donde el cuerpo no es más que todo lo que es. Un cuerpo como colección de piezas, lleno de pedazos, fragmentos, órganos, tejidos, tal como la imagen de la disección impulsada por Vesalio, pero no organizado. Un cuerpo como simple envoltura, contenedor finito de lo infinito; pues cuerpo es desenvolvimiento del cuerpo, el que, además, es siempre deforme, pues lo liso no es más que un diseño discursivo, como plantea Nancy. Un cuerpo construido a base de indicios, que niega la totalidad o una unidad sintética del mismo y que exalta su permanente oxímoron de ser: al mismo tiempo, un dentro y un afuera, una materia y una forma. La expresión, entonces, de una metonimia, parte por partes. Un cuerpo que es expresión de incertidumbre, que es extraño y propio a la vez, que no tiene lugar, ni en el discurso, ni en la materia, sino en el límite, espaciamento sin forma y sin idea:

Un cuerpo es una imagen ofrecida a otros cuerpos, todo un corpus de imágenes que pasan de un cuerpo a otro, colores, sombras locales, fragmentos, granos, areolas, lúnulas, uñas, pelos, tendones, cráneos, costillas, pelvis, vientres, meatos, espumas, lágrimas, dientes, babas, fisuras, bloques, lenguas, sudores, licores, venas, penas y alegrías, y yo, y tú (Nancy 83).

La escritura de Palazuelos se compone y descompone según el predicamento de una corporalidad que se excede a sí misma, a un tiempo desbordando e intensificando sus propios límites y reconociendo su propio fracaso: "Somos grandes pájaros derrotados por el sueño de un sueño casi cumplido" (Palazuelos, La Visitadora 303).

\section{LA ANOMALÍA URDIDA A TRAVÉS DE LA MELANCOLÍA}

Conocidos son los comentarios de Benjamin sobre el concepto de melancolía en relación con el barroco: la bilis negra expresaría el aspecto fúnebre, el fantasma, de un origen irremediablemente perdido y al sujeto solo le queda aprehender el mundo fragmentariamente. Bieńczyk anota: “... la imaginación barroca, con su gusto por acumular fragmentos, trozos, migajas de cosas, favorece de una manera especial un estilo melancólico de comportamiento y la necesidad de máscaras y cortinas" (38). Continúa: 
El modo de existencia que impone la melancolía tanto al hombre como a la cultura es el palimpsesto: añadirse a la existencia de algo que ya existe, a un texto que ya estaba escrito, inscribirse en él, en su interior, a un lado o al margen. En la literatura es el manuscrito recuperado, el libro dentro del libro, el mito del primer volumen perdido, el mundo como teatro, biblioteca y enciclopedia; y también, en general, el rechazo hacia cualquier tipo de vanguardia dogmática (39).

Señala, además, que el funcionamiento de la melancolía es el de una molécula solitaria que busca generar un vínculo con otra a través de la metonimia mediante la atracción de otros fragmentos, cualesquiera, para alcanzar una nueva forma de organicidad. Pero no solo opera como metonimia, sino también como oxímoron donde la negrura se encuentra con la luz: "La retórica de la estética melancólica suele llevar la fuerza de la expresión a la materia misma de la lengua, desligar las palabras de las cosas" (56):

O como en la acumulación barroca de asociaciones y reflejos, en la que las palabras giran violentamente en torno a los objetos y hacen de cada uno no el lugar de un significado, sino un vacío que se puede rellenar con cualquier sentido: palabras que maltratan de alguna manera a las cosas, bombardeándolas con su exceso, con la agotadora imprecisión de sus decisiones. Cuando la melancolía no llega a la íntima esencia de las cosas, a lo que en ellas existe sin contradicción, a lo que es fundamental pues forma parte de su estructura; cuando advierte, por encima de todo, su segundo fondo, su ausencia corrosiva y lo absurdo en su masa, y no sabe mostrar las cosas como son en su representación más evidente; entonces, ante esa imposibilidad de representar las cosas, la lengua se vuelve ojo, y el habla, una manera de ver (57).

La melancolía se opone, de esta manera, a la contemplación, pues la mirada se vuelve sobre sí misma y no se transitiviza hacia el objeto para lograr la consumación (gasto/realización): "La perspectiva ya no es entonces un instrumento de unidad, sino de dispersión. Cada persona, cada objeto, cada forma parece ahora ser membra disiecta, trozos dispersos, fragmentos aprisionados en la soledad, en una presencia informe e insegura" (91).

Ante la pregunta realizada a Kierkegaard sobre cuál es el significado de melancolía, éste responde:

Es una histeria del alma. En la vida de las personas tiene lugar un instante en el que lo inmediato madura, cuando el alma exige adoptar 
la forma de un ente superior para poder verse a sí misma como un espíritu. La inmediatez del alma relaciona al ser humano con toda su vida temporal, y ahora el alma quiere salirse de ese estado de dispersión para explicarse a sí misma; la individualidad tiende a alcanzar la conciencia de su significado eterno. Si no lo consigue, se estanca, el espíritu es silenciado y es entonces cuando da muestras de existencia la melancolía (Cit. en Bieńczyk131-132).

La imposibilidad de alcanzar la formalización parece coincidir con lo señalado por Didi-Huberman con respecto a la invención de la histeria:

...el paso al trazo, la realización de un grabado a partir de una fotografía, seguía siendo la operación necesaria para la utilización y transmisión de los clichés. [...] Ahora bien, en este paso siempre se olvidaba o se infringía algo, pese a la pasión por la exactitud que alegaba Diamond. Lo mismo ocurría con el emplazamiento. Veamos a esta mujer sentada en un exterior, sin duda en un patio para contar con más luz, y detrás de la que se ha colocado una cortina [...]; en el grabado, esta mujer está en ninguna parte, ¿cómo no mostrarse, pues, perturbada, con la mirada así dibujada y privada de espacio y de destino? [...]... la leyenda de esos grabados designaba no tanto un atributo del referente ("melancólica") como un concepto ("Melancolía") (57-59).

Entonces, trastorno, anomalía, enfermedad que trae este mal sin causa conocida: malum sine materia.

El propio Charcot admitía que la histeria y las enfermedades cercanas a ella, como la epilepsia o la corea o baile de San Vito, "se nos ofrecen como una esfinge que desafía la anatomía más penetrante". Parece como si la histeria no sólo fuera capaz de escapar a las reglas del método anatómico-clínico, y de la denominada "doctrina de las localizaciones", sino que también, como explica Charcot, no hace más que intervenir "peligrosamente", es decir, como causante de errores. /Causante de errores, sí. Y es que la histeria supone, en esencia, un golpe paradójico de monumentales proporciones asestado a la inteligibilidad médica: un mal que no es de "sede", sino de recorridos, de localizaciones múltiples. Un mal que no es de "causa", sino de quasi-causas, con estatutos temporales y antitéticos, de quasi-causas diseminadas, y cuya eficacia sería más bien la de la propia paradoja que la encierra, es decir, la génesis en acción, siempre en acción, de la contradicción (99). 
Así, esta paradoja hace que la textualidad se espectacularice en la acedía histérica como manifestación de un conflicto que recorre todo el gesto. No solo ininteligibilidad, sino también ilegibilidad ante los textos de un Palazuelos que no sigue el cauce de la literatura chilena de esos años, sino que busca refugiarse en la escritura de Huidobro, como puede apreciarse en este pasaje de Muy temprano para Santiago:

Tercero: aves: una gaviota eleva el mar al robarse el contorno de una ola; un cometocino infla la hojas de un boldo, es decir, una rama convertida en pájaro cae hacia arriba hasta detenerse algunos segundos y luego rueda por el firmamento hasta desaparecer en otra rama, cuyas hojas, de un verde descolorido y casi transparente, señalan al pitosporo; muy cerca varias moscas juegan a ser minúsculos pájaros de piedra oscura. Cuarto: música: mi respiración y el aire inundado de golpes de agua y latigazos de los güiros sobre las rocas, ejecutan una fuga interminable de elemental contrapunto ${ }^{25}$ (18).

\section{ANAMORFOSIS ${ }^{26}$ Y METAMORFOSIS MELANCÓLICAS}

25 La contradicción entre caída y ascensión muestra semejanzas con Altazor (1931). Fuga y contrapunto están ligados paradigmáticamente a la música barroca: véase las referencias a Bach en Según el orden del tiempo.

26 "Sombra en lugar de materia perenne, reflejo en lugar de forma, la perspectiva descompuesta. [...]. La realidad vista a través del ojo melancólico parece haberse entregado a una anamorfosis continua (una deformación óptica) en la que una figura empuja a una forma ya existente a la contradicción; así es esa realidad, tan poco esencial, tan poco estable y tan sensible a la deformación. [...] Las formas se vuelven estáticas: sacadas de su estado, stasis, conducidas a una aparición poco duradera, apretadas o amasadas en su superficie. La anamorfosis, la «proyección de la forma fuera de sí misma», como afirma en una de sus definiciones Baltrušaitis, significa según su genealogía (ana-morphe) la elevación (ana) de la forma (morphe), mejor dicho, la vuelta, el alejamiento de una forma en virtud de otra para que la resultante sea nueva, cambie, se deforme. El prefijo ana-, que alude precisamente al salir, al «afuera» (la dirección es vertical, hacia arriba), trae a la mente la anamnesis platónica según la cual encontramos en la memoria aquello que ya conocimos en el mundo -elevado- de las ideas. Pero en la anamorfosis melancólica el movimiento de desechar las formas vistas, de transformarlas en otras, no conocer por supuesto ninguna referencia ideal más allá de la Nada, la única esencia de la realidad asible para la melancolía. Si la melancolía es platónica, lo es precisamente de una manera negativa, en su pérfida tendencia a alcanzar esa idea primera que es el vacío, un lugar al que se regresa desde el mundo de las formas: la «tumba vacía» del verso de Baudelaire" (Bieńczyk 91-92). 
La mágica mirada melancólica ${ }^{27}$ recorre rápida e impacientemente las superficies textuales y encuentra solo ilusiones, simulaciones y deformaciones:

La anamorfosis es una figura conocida en la arquitectura y el arte barrocos (la palabra se empezó a utilizar en la segunda mitad del siglo XVIII), un instrumento para hacer "trucos de magia" gracias a los que, jugando con la perspectiva, se pueden alcanzar efectos ilusorios, efectos de acercamiento y alejamiento (Bieńczyk 92-93).

Sarduy señala, por otra parte, que es esta mirada la que otorga verosimilitud a la representación por parte del ojo melancólico que se mira a sí mismo y no encuentra nada que ver:

Es el vacío o el cero inicial, el que en su mímesis y simulacro de forma proyecta un uno del cual partirá toda la serie de los números y de las cosas, estallido inicial de no un átomo de hipermateria-como lo postulan las teorías cosmológicas actuales- sino de una pura nopresencia que se trasviste en pura energía, engendrando lo visible con su simulacro (61).

Simulación o disimulación, pero siempre fingimiento: ausencia presente o presencia ausente, afirma Baudrillard; predominio del parecer sobre el ser, dice Rousset. Y Sarduy, por último, señala que responde a una estrategia de teatralidad y saturación:

En el operar preciso de una lectura barroco de la anamorfosis, un primer movimiento, paralelo al del analista, asimila en efecto a lo real la imagen "difusa y rota"; pero un segundo gesto, el propiamente barroco, de alejamiento y especificación del objeto, crítica de lo figurado, lo desasimila de lo real: de esa reducción a su propio mecanismo técnico, a la teatralidad de la simulación, es la verdad barroca de la anamorfosis. [...] La anamorfosis y el discurso del analizante como forma de ocultación: algo se oculta al sujeto - de allí su malestarque no se revelará más que gracias a un cambio de sitio. El sujeto

27 "Todos los razonamientos comunes sobre el cuerpo terminan en algo de sombra y de opacidad en torno a un hueso (en el embudo ético, en la melancolía de lo finito): a veces comienzan bien, para luego terminar de cualquier manera...Si son necesarios los apuntalamientos lógicos, quiere decir que hay descomposición, riesgo de derrumbamientos. Observando este cuerpo, el pensamiento comprende que tiene mejores cosas que hacer, antes que definir o desear" (Ceronetti 56). 
está implicado en la lectura del espectáculo, en el desciframiento del discurso, precisamente porque eso que de inmediato no logra oír o ver lo que concierne directamente en tanto que sujeto (64-66).

La ilegibilidad se re-vela, esto es, se manifiesta y oculta al mismo tiempo, en un melancólico modo de lectura que se desplaza metonímicamente hacia la alegoría en su intento por olvidar la cerrazón del símbolo:

...la anamorfosis, al contrario se presenta como una opacidad inicial y reconstituye, en el desplazamiento del sujeto que implica, la trayectoria mental de la alegoría, que se capta cuando el pensamiento abandona la perspectiva directa, frontal, para situarse oblicuamente con relación al texto, como ya lo sostenía Galileo (Sarduy 67).

Oblicuidad de la mirada que no cede a las tentaciones de linealidad, unidad, organicidad y absoluto. Por el contrario, la anamorfosis plasma un movimiento plástico que hace de la abertura, la apertura hacia sentidos relativos: la polisemia de un jarrón desbordando sentido:

El jarrón Ming ha desaparecido de súbito. Vuelve a surgir el de greda y lo substituye por completo. [...] Hexe mostrándolo con el dedo. Es viejo, pero sus formas brillan y se destacan. Estilización a causa del tiempo. Está lleno de tiempo. Líneas suaves y ondulantes. Su contorno. Su cuerpo. Red de sombras sobre una pequeña parte. Es un retamo reseco. La red se mueve lentamente, dándole vida. Sol que se esconde. Se desvanece ese brillo externo. Y toda la greda pulida por miles de dedos sobre ella se ilumina por sí misma. Detrás está el jarrón Ming. Son uno solo, a pesar de que el más rústico significa: tarde de primavera con Hexe, plenitud, alegría, intrascendencia; y el otro: calle Ejército, vacío, desazón, trascendencia (Palazuelos, Según el orden del tiempo 57-58).

Asimismo, no solo la mirada sino que también la materialidad ofrecida a dicho mirar se entrega a un devenir incesante para vulnerar las identidades: enmascaramiento del rostro y ocultamiento de la mirada se dinamizan caleidoscópicamente en composiciones y descomposiciones, metamorfosis, de una realidad que gira alrededor de sí misma, inscribiéndose en el circular movimiento de su imagen que se presenta, desde su anagrama, como enigma. Mirada y materia gozan con la distorsión de su repliegue especular y, por lo tanto, la escritura se fuga o excribe de toda estancia fija en una unidad e identidad: 
Circe es la maga que transforma un hombre en animal, y otra vez en hombre; que presta y retira a cada uno todos los cuerpos y figuras; ya no hay caras, sino máscaras; toca las cosas y éstas ya no son lo que eran; mira el paisaje y éste se transforma. Parece como si, en su presencia el universo pierda su unidad, el suelo su estabilidad y los seres su identidad; todo se descompone para volver a recomponerse arrastrado por el flujo de una incesante mutación, un juego de apariencias en constante huida frente a otras apariencias" (Rousett 17-18).

El poder de Circe, la metamorfosis, provoca que solo la ausencia de una esencia constituya la única esencia asignable a un habitar proteico de un cuerpo en devenir: "La calle como un río que se queda súbitamente a secas. La gente salta como peces sorprendidos. O camina. [...] Otra luz ilumina la habitación. Otras sombras, por supuesto. Los objetos cambian de ropa. Son siempre los mismos, pero con otras vestiduras" (Palazuelos, Según el orden del tiempo 27).

En conclusión, los textos de Palazuelos, aunque con grandes diferencias, exhiben un funcionamiento metonímico, alegórico, dentro del cuerpo escritural que prolifera intensa y extensamente ${ }^{28}$ a través de rastros, acaso huellas. Trazos y retrasos, circulando erráticamente. Gestos, rasgos, aspecto fúnebre. Aunque autor y autoridad frente a la institucionalidad en su contienda, éste se vuelca en una escritura que recorre mecanográficamente la superficie textual, tejiendo y destejiendo a través de una máquina estilística que disecta miembros en La visitadora, Según el orden del tiempo y Muy temprano para Santiago.

En julio del año pasado, el poeta y novelista Leonardo Sanhueza publicó en Las Últimas Noticias una reseña sobre la reedición de estas antinovelas en la que destaca la condición de autor de culto de Palazuelos. Además, Sanhueza coincide con la perspectiva de este trabajo en tanto da cuenta de la opinión de una crítica que consideró a Palazuelos como una promesa incumplida. Así, la de Palazuelos consistiría en una obra que "perdura hasta hoy no sólo en el anecdotario de la historia literaria chilena, sino en la interrogante abierta que dejaron sus potencialidades" (Sanhueza 50). Lo que la escritura palazueliana pudo y puede ser, por su carácter anamórfico y metamórfico, multiplica las

28 “[...] el cuerpo es la materia plástica del espaciamiento sin forma y sin Idea. Es la plasticidad misma de la expansión, de la extensión según la cual tienen lugar las existencias. [...]. El cuerpo no es imagen-de. Pero es venida a presencia" (Nancy 51). 
significaciones posibles para derrumbar así todo binarismo, incluyendo el que enfrenta a la novela con la antinovela.

\section{BIBLIOGRAFÍA}

Alegría, Fernando. “Antiliteratura”. En Fernández Moreno, César. América Latina en su literatura. México: Siglo XXI, 1988.

Bieńczyk, Marek. Melancolía. De los que la dicha perdieron y no la hallarán más. Trad. Maila Lema. Barcelona: Acantilado, 2014.

Briseño, Roberto. “Según el orden del tiempo”. El Mercurio (Santiago, 17 mar. 1963).

Cabrera, Orlando. "La revelación literaria de 1962. Juan Agustín Palazuelos, un hombre en busca de un estilo". Revista Zig-Zag (Santiago, 04 ene. 1963).

Carroll, Lewis. Alicia en el país de las maravillas. Trad. Jaime de Ojeda. Madrid: Alianza Editorial, 1972.

Castro, Américo. "Antonio de Guevara. Un hombre y un estilo del siglo XVI". THESAURUS. Boletín del Instituto Caro y Cuervo. Tomo I. Núm. 1. Bogotá, 1945.

Ceronetti, Guido. "Sobre un desnudo fotográfico de 1930". El monóculo melancólico. Trad. de M. A. Barbuto. Barcelona: Acantilado, 2013.

Courtine, Jean-Jacques. "El cuerpo inhumano". En VV. AA. Historia del cuerpo. Bajo la dirección de Alain Corbin, Jean-Jacques Courtine y Georges Vigarello. Madrid: Taurus, 2005. V.1.

Del Solar, Hernán. "Juan Agustín Palazuelos: Según el orden del tiempo". La Nación (Santiago, 25 ene. 1963).

Deleuze,Gilles y Félix Guattari. “CCómo hacerse un cuerpo sin órganos?”. Mil Mesetas: capitalismo y esquizofrenia. Valencia: Pre-Textos, 1997.

Derrida, Jacques. La verdad en pintura. Trad. M.C. González y D. Scavino. Buenos Aires: Paidós, 2001.

Didi-Huberman, Georges. La invención de la histeria: Charcot y la iconografía fotográfica de la Salpêtrière. Trad. Tania Arias y Rafael Jackson. Madrid: Cátedra, 2007.

Drago, Gonzalo. "Según el orden del tiempo (novela de Juan Agustín Palazuelos)”. El Diario de Malleco (Angol, 01 jul. 1963).

Echavarren, Roberto et al. Medusario. Muestra de poesía latinoamericana. Buenos Aires: Mansalva, 2010.

Estébanez, Demetrio. Diccionario de términos literarios. Madrid: Alianza, 2001.

Filebo (Luis Sánchez Latorre). “Los Novísimos”. Las Últimas Noticias (Santiago, 16 oct. 2000).

G.B. "Palazuelos madruga". Revista Ercilla (Santiago 05 ene. 1966).

Gelcic, Ricardo. "Según el orden del tiempo de Juan Agustín Palazuelos”. El Mercurio (Santiago, 17 feb. 1963).

Genette, Gérard. Umbrales. México: Siglo XXI, 2001. 
Gutiérrez Carbajo. "La crítica estilística de Amado Alonso. Su interpretación de Pablo Neruda". Cauce Nrs. 18-19. Centro Virtual Cervantes.

Horacio. "Sátiras y epístolas". Obras completas. Tomo II. Madrid: Librería Perlado, Páez y Cía., 1909.

Latcham, Ricardo. "Tres novelas chilenas". Revista La Nación (Santiago, 03 feb. 1963).

Leibniz, G. W. Escritos filosóficos. Editados por Ezequiel de Olaso. Buenos Aires: Charcas, 1982.

López Martínez, María. Neruda y los escritores de la Edad de Oro. Sevilla: Consejo Superior de Investigaciones Científicas, Escuela de Estudios Hispano-Americanos, Universidad de Sevilla, 2009.

M.C.G. "Según el orden del tiempo, novela por Juan Agustín Palazuelos. Editorial Zig-Zag, 1968. Segunda edición”. Libros y revistas (Santiago, 21 mar. 1969).

Mandressi, Rafael. "Disecciones y anatomías". En VV. AA. Historia del cuerpo. V. 1. Bajo la dirección de Alain Corbin, Jean-Jacques Courtine y Georges Vigarello. Madrid: Taurus, 2005.

Marchant, Patricio. Escritura y temblor. Santiago: Cuarto Propio, 2000.

Matte Alessandri, Ester. "Juan Agustín Palazuelos: Según el orden del tiempo". Revista Mapocho. Tomo I, nº 2, v.1 (Santiago, jul. 1963). Pp. 263-265.

Nancy, Jean-Luc. Corpus. Madrid: Arena, 2003.

Palazuelos, Juan Agustín. "La Visitadora”. Revista Mapocho. Tomo II, nº1, v.4 (Santiago, mar. 1964). Pp. 230-233.

Muy temprano para Santiago. Santiago: Zig-Zag, 1965.

Según el orden del tiempo. Santiago: Cuneta, 2014.

Quesada, Catalina. La metanovela hispanoamericana en el último tercio del siglo XX. Madrid: Arco/Libros, 2009.

Rousset, Jean. Circe y el pavo real. La literatura francesa del Barroco. Trad. Jordi Marfà. Barcelona: Six Barral, 1972.

Sanhueza, Leonardo. "Reeditan las dos únicas novelas de Juan-Agustín Palazuelos". Las Últimas Noticias (Santiago, 7 jul. 2014).

Sarduy, Severo. "La simulación". Ensayos generales sobre el barroco. Buenos Aires: Fondo de Cultura Económica, 1987.

Sebreli, Juan José. Las aventuras de la vanguardia. El arte moderno contra la modernidad. Buenos Aires: Sudamericana, 2002.

Tejeda, Juan. "Muy temprano para Santiago. Novela de Juan Agustín Palazuelos, Ed. ZigZag”. La Nación (Santiago, 13 mar. 1966). 